Wicaksono Putra Hariyadi, Perlindungan Hukum Hak-Hak Masyarakat Hukum Adat Terhadap Dampak Negatif Illegal Logging, Halaman 234-246

\title{
PERLINDUNGAN HUKUM HAK-HAK MASYARAKAT HUKUM ADAT TERHADAP DAMPAK NEGATIF ILLEGAL LOGGING
}

\author{
Wicaksono Putra Hariyadi \\ Fakultas Hukum Universitas Muhammadiyah Palembang \\ Email: wicaksono.putra90@yahoo.com
}

\begin{abstract}
Forest damage due to illegal logging and logging is known as illegal logging. Legal protection of the rights of indigenous and tribal peoples to the negative impacts of illegal logging based on the concept of national law and customary law can be done by protecting the interests of indigenous peoples, particularly through legislation, namely Article 67 Article (1) (2) and (3) of the Law Law No. 41 of 1999 concerning Forestry. The need for legal protection for indigenous peoples is vulnerable to violations or neglect of their human rights. The state has the responsibility to promote, protect and uphold human rights against its citizens.
\end{abstract}

Keywords: Customary Law; Illegal Logging

\begin{abstract}
Abstrak
Kerusakan hutan akibat pencurian kayu dan penebangan tanpa izin atau dikenal dengan illegal logging. Perlindungan hukum hak-hak masyarakat hukum adat terhadap dampak negatif illegal logging berdasarkan konsep hukum nasional dan hukum adat dapat dilakukan dengan melindungi kepentingan masyarakat adat, khususnya melalui peraturan perundang-undangan yaitu dalam Pasal 67 Pasal (1) (2) dan (3) Undang-Undang Nomor 41 Tahun 1999 tentang Kehutanan. Perlunya perlindungan hukum bagi masyarakat adat rentan terhadap pelanggaran atau pengabaian hak asasinya. Negara mempunyai tanggung jawab untuk memajukan, melindungi serta menegakkan hak asasi manusia terhadap warganya.
\end{abstract}

Kata Kunci: Hukum Adat; Illegal Logging

\section{PENDAHULUAN}

Hutan mempuyai kedudukan dan peranan yang sangat penting dalam pembangunan bangsa dan negara. Hutan mempunyai banyak manfaat yang sebesar-besarnya bagi kemakmuran dan kesejahteraan rakyat. Oleh karena itu, hutan harus dilindungi sehingga dapat memberikan manfaatnya bagi kebutuhan hidup manusia secara terus menerus. Dalam ketentuan Pasal 47 Undang-Undang Nomor 41 Tahun 1999 tentang Kehutanan ditentukan bahwa perlindungan hutan dan kawasan hutan merupakan usaha untuk (1) mencegah dan membatasi kerusakan hutan, kawasan hutan dan hasil hutang yang disebapkan oleh perbuatan manusia, ternak, kebakaran, daya-daya alam, hama dan penyakit, dan (2) mempertahankan dan menjaga hak-hak negara, masyarakat dan perorangan atas hutan, kawasan hutan, hasil hutan, investasi serta 
Wicaksono Putra Hariyadi, Perlindungan Hukum Hak-Hak Masyarakat Hukum Adat Terhadap Dampak Negatif Illegal Logging, Halaman 234-246

perangkat yang berhubungan dengan pengelolaan.

Berbagai usaha perlindungan terhadap hutan telah dilakukan, namun pada penerapannya usaha yang dilakukan tersebut masih belum maksimal hal ini dibuktikan dengan masih banyaknya kerusakan hutan yang terjadi. Ada lima golongan kerusakan hutan yaitu sebagai berikut:

a. Kerusakan hutan akibat pengerjaan atau pendudukan tanah hutan secara tidak sah, penggunaan hutan yang menyimpang dari fungsinya dan pengusahaan hutan yang tidak sesuai dengan fungsinya;

b. Kerusakan hutan akibat pengambilan batu, tanah, bahan galian lainnya serta penggunaan alat-alat yang tidak sesuai dengan kondisi tanah;

c. Kerusakan hutan akibat pencurian kayu dan penebangan tanpa izin;

d. Kerusakan hutan akibat pengembalaan ternak dan akibat kebakaran;

e. Kerusakan hasil hutan akibat perbuatan manusia, hama dan penyakit serta daya alam. ${ }^{1}$

1 Salim HS, Dasar-Dasar Hukum Kehutanan, Jakarta: Sinar Grafika, 2008, hlm.114.
Berdasarkan macam-macam kerusakan hutan tersebut satu diantaranya adalah kerusakan hutan akibat pencurian kayu dan penebangan tanpa izin atau dikenal dengan illegal logging. Menurut Sukardi kalau ditelusuri secara cermat pengertian illegal logging dalam peraturan perundang-undangan khususnya dalam Undang-Undang Kehutanan maka tidak ditemukan secara jelas pengaturan mengenai hal tersebut. Dalam The Contemporary English Indonesian Dictionary sebagaimana yang dikutip Salim menyatakan bahwa illegal artinya forbidden by law, unlawful's artinya yang dilarang menurut hukum. Log dalam bahasa Inggris artinya batang kayu atau kayu gelondongan. Logging artinya menebang kayu dan membawa ketempat gergajian.

Menurut Sukardi berdasarkan pengertian secara harfiah tersebut dapat dikatakan bahwa illegal logging menurut bahasa berarti menebang kayu dan membawa ke tempat gergajian yang bertentangan dengan hukum atau tidak sah menurut hukum. Dalam Instruksi Presiden Republik Indonesia Nomor 5 Tahun 2001 tentang Pemberantasan Penebangan Kayu Ilegal (illegal logging) dan Peredaran hasil hutan illegal dikawasan Ekosistem Leuser dan Taman 
Wicaksono Putra Hariyadi, Perlindungan Hukum Hak-Hak Masyarakat Hukum Adat Terhadap Dampak Negatif Illegal Logging, Halaman 234-246

Nasional Tanjung Putting istilah Illegal

Logging diartikan sebagai penebangan kayu illegal tidak sah. Istilah illegal logging disinonimkan dengan penebangan kayu tidak sah. ${ }^{2}$

Berdasarkan uraian diatas menunjukkan bahwa adanya illegal logging yang berlangsung secara terus menerus dan dalam jangka waktu yang lama akan mengancam kehidupan suatu masyarakat yang memenuhi kebutuhan hidupnya melalui hasil hutan tersebut. Dengan adanya illegal logging ini masyarakat yang mendiami suatu wilayah akan mengalami rasa kekahwatiran terhadap kelangsungan kehidupan mereka. Suatu masyarakat merupakan suatu bentuk kehidupan bersama, yang warga negaranya hidup bersama untuk jangka waktu yang cukup lama, sehingga menghasilkan kebudayaan. Masyarakat indonesia di dalam susansa lingkungan rakyat merupakan persekutuan yang disebut persekutan hukum. Masing-masing persekutuan hukum teresbut merupakan kesatuan yang menmpunyai anggota-anggota dalam lingkungannya diantara anggota kesatuan tesrsbut mempunyai hubungan erat,

2 Supriadi, Hukum Kehutanan dan Hukum Perkebunan di Indonesia, Jakarta: Sinar Grafika, 2010, hlm. 299. anggota-anggota merupakan bagian dari kesatuan tersbut didalam pertaliannya dengan kesatuan keseluruhnya. ${ }^{3}$ Masyarakat merupakan suatu sistem sosial, yang menjadi wadah dari pola-pola interaksi sosial atau hubungan interpersonal maupun hubungan kelompok sosial. Masyarakat yang dimaksud disini merupakan penduduk asli (indigenous people).

Berdasarkan ukuran atau standar kelestarian yang dikembangkan International Timber Tropical Organization (ITTO), Forest Stewardship Council (FSC), Lembaga Ekolabael Indonesia (LEI), Pan-European Forest Certification (PEFC) dan Departemen Kehutanan dalam kaitannya dengan istilah kelestarian sosial dijumpai beberapa istilah yang berhubungan dengan istilah masyarakat lokal, salah satunya penduduk asli (indigenous people). ${ }^{4}$ Pengertian masyarakat lokal dalam khasanah kajian peraturan perundang-undangan pengelolaan sumber daya hutan terbagi atas masyarakat hukum adat dan masyarakat

3 Chairul Anwar, Hukum Adat Indonesia “Meninjau Hukum Adat Minangkabau”, Jakarta: Rineka Cipta, Jakarta, 1997, hlm.7.

${ }^{4}$ Abdul Muis Yusuf dan Mohammad Taufik Makarao, Hukum Kehutanan di Indonesia, Jakarta: Rineka Cipta, 2011, hlm. 246. 
Wicaksono Putra Hariyadi, Perlindungan Hukum Hak-Hak Masyarakat Hukum Adat Terhadap Dampak Negatif Illegal Logging, Halaman 234-246

di dalam dan sekitar hutan. Istilah masyarakat hukum adat banyak digunakan dalam peraturan perundang-undangan namun belum ada satu peraturan yang memberi penjelasan mengenai makna masyarakat hukum adat.

Pengertian masyarakat hukum adat menurut Terhaar adalah kelompok masyarakat yang teratur, besifat tetap mempunyai kekuasan dan kekayaan sensitif baik berupa benda terlihat maupun tidak terlihat. Hak pengelolaan sumber hutan bagi masyarakat hukum adat didasarkan atas UUPA Pasal 2 ayat 4. Hak masyarakat hukum adat untuk mengelola sumber daya hutan adalah hak menurut sumber hukum nasional bersumber dari delegasi wewenang hak menguasai negara kepada masyarakat hukum adat yang bersangkutan.

Di dalam bukunya yang berjudul Beginselen en Stelsel van het Adatrecht, Ter Haar merumuskan masyarakat hukum sebagai kelompok-kelompok teratur yang sifatnya ajek dengan pemerintahan sendiri yang memiliki benda-benda materiel maupun immateriel. Selanjutnya Hazairin menyatakan bahwa masyarakat-masyarakat hukum adat juga terangkum dalam Pasal 18
Undang-Undang Dasar 1945 yang isinya sebagai berikut "Pembagian daerah Indonesia atas dasar daerah besar dan kecil, dengan bentuk susunan pemerintahannya ditetapkan dengan undang-undang, dengan memandang dan mengingati dasar permusyawaratan dalam sistem pemerintahan negara dan hak-hak asal-usul dalam daerah yang bersifat istimewa. ${ }^{5}$

Berdasarkan uraian pakar ahli hukum mengenai konsep masyarakat hukum adat menunjukkan bahwa keberadaan masyarakat hukum adat dalam kaitannya untuk memperoleh haknya memanfaatkan dan menikmati hasil dari sumber daya hutan merupakan hak yang telah diatur menurut sumber hukum nasional yang bersumber dari delegasi wewenang hak menguasai negara kepada masyarakat hukum adat yang bersangkutan. Akan tetapi hak masyarakat hukum adat ini didalam penerapannya terjadi benturan antara hukum nasional dan hukum adat mengenai konsep perlindungan hukum yang diberikan. Dimana hukum nasional akan mengakui keberadaan hak-hak masyarakat hukum adat sepanjang tidak bertentangan dengan aturan-aturan

5 Soerjono Soekanto, Hukum Adat Indonesia, Jakarta: PT. RajaGrafindo Persada, 2007, hlm. 93-94. 
Wicaksono Putra Hariyadi, Perlindungan Hukum Hak-Hak Masyarakat Hukum Adat Terhadap Dampak Negatif Illegal Logging, Halaman 234-246

hukum yang berlaku dalam peraturan perundang-undangan. Hal ini menunjukkan bahwa hukum adat tidak lagi menjadi sumber hukum nasional, ditambah lagi dengan kenyataan bahwa sampai sekarang masih belum terdapat kejelasan dimana letak hukum adat dalam kerangka tata urutan peraturan perundang-undangan. Ketentuan ini sebagaimana dijelaskan dalam Ketetapan Majelis Permusyawaratan Sementara Tahun 1960 No. II (Lampiran A) hukum adat ditegaskan sebagai landasan hukum nasional. Ini adalah satu-satunya Ketetapan Majelis Permusyawaratan Rakyat yang pernah ada di dalam sejarah kehidupan Hukum Adat setelah tahun 1945. Ketetapan Majelis ini dalam tahun-tahun berikutnya ternyata tidak pernah lagi menyebutkan dengan tegas hukum adat adalah kerangka tata hukum nasional di Indonesia. ${ }^{6}$ Hal ini menunjukkan adanya pandangan bahwa hukum adat merupakan hukum yang masih dapat ditolerir sejauh sesuai dengan hukum nasional yang disusun secara modern. Dengan begitu akhirnya segalanya akan diganti dengan hukum modern.

\footnotetext{
6 Moh. Koesnoe, Hukum Adat Sebagi Suatu Model Hukum, Bandung: CV. Mandar Maju, 1992, hlm. 25.
}

Permasalahan dalam penelitian ini adalah bagaimanakah bentuk dan mekanisme perlindungan hukum hak-hak masyarakat hukum adat terhadap dampak negatif illegal logging berdasarkan konsep hukum nasional dan hukum adat.

\section{PEMBAHASAN}

\section{A. Pengertian Perlindungan Hukum}

Hukum berfungsi untuk melindungi masyarakat dan individu terhadap perbuatan-perbuatan yang mengganggu tata tertib masyarakat yang dilakukan oleh individu-individu lain atau pemerintah sendiri (penyalahgunaan wewenang yang dilakukan oleh para petugas negara) maupun pemerintah asing (agresi atau subversi yang dilakukan pemerintah asing). ${ }^{7}$ Hal ini diperkuat dengan pendapat Roscue Pond yang mengemukakan bahwa hukum untuk melindungi kepentingan manusia (law as tool of social engineering), dikarenakan kepantingan manusia adalah suatu tuntutan yang dilindungi dan dipenuhi manusia dalam bidang hukum. ${ }^{8}$ Berbagai konsep pengertian perlindungan hukum ditemukan pada berbagai peraturan perundang-undangan,

\footnotetext{
${ }^{7}$ E.Utrecht dan Moh. Saleh Djindang, Pengantar dalam Hukum Indonbesia, Jakarta: PT Ichtiar Baru, Anggota IKAPI dan Penerbit Sinar Harapan, 1989, hlm.15.

${ }^{8}$ Salim HS, Perkembangan Teori dalam Ilmu Hukum, Jakarta: Rajawali Pers, 2010, hlm.41-42.
} 
Wicaksono Putra Hariyadi, Perlindungan Hukum Hak-Hak Masyarakat Hukum Adat Terhadap Dampak Negatif Illegal Logging, Halaman 234-246

satu diantaranya pengertian perlindungan hukum menurut Undang-Undang Nomor 40 Tahun 1999 tentang Pers menyatakan bahwa perlindungan hukum adalah jaminan perlindungan pemerintah dan atau masyarakat kepada warga negara dalam melaksanakan fungsi, hak, kewajiban dan peranannya sesuai dengan ketentuan peraturan perundang-undangan yang berlaku.

\section{Berdasarkan}

ketentuan

Undang-Undang Nomor 23 tahun 2004 tentang Penghapusan Kekerasan dalam Rumah Tangga menyatakan bahwa perlindungan adalah segala upaya yang ditujukan untuk memberikan rasa aman kepada kornan yang dilakukan oleh pihak keluarga, advokat, lembaga sosial, kepolisian, kejaksaan, pengadilan, atau pihak lainnya baik sementara maupun berdasarkan penetapan pengadilan. Sedangkan dalam Peraturan Pemerintah Nomor 2 Tahun 2002 tentang Tata Cara Perlindungan terhadap Korban dan Saksi dalam Pelanggaran Hak Asasi Manusia yang Berat menyatakan bahwa perlindungan adalah suatu bentuk pelayanan yang wajib dilaksanakan oleh aparat penegak hukum atau aparat keamanan untuk memberikan rasa aman baik fisik maupun mental, kepada korban dan saksi dari ancaman, gangguan teror, dan kekerasan dari pihak manapun yang diberikan pada tahap penyelidikan, penyidikan, dan atau pemeriksaan di sidang pengadilan.

Hukum menurut J.C.T. Simorangkir, SH dan Woerjono Sastropranoto, $\mathrm{SH}$ merupakan peraturan-peraturan yang bersifat memaksa, yang menentukan tingkah laku manusia dalam lingkungan masyarakat yang dibuat oleh badan-badan resmi yang berwajib,pelanggaran mana terhadap peraturan-peraturan tadi berakibatkan diambilnya tindakan, yaitu dengan hukuman tertentu. ${ }^{9}$ Hukum menurut Drs E.Utrecht, S.H merupakan himpunan peraturan-peraturan (perintah-perintah dan larangan-larangan) yang mengurus tata tertib masyarakat dan oleh karena itu harus ditaati masyarakat itu. ${ }^{10}$

Berdasarkan uraian diatas, dapat dijelaskan bahwa pengertian perlindungan hukum adalah perlindungan yang diberikan kepada subjek hukum yang bersifat preventif maupun yang bersifat represif, baik yang tertulis maupun tidak tertulis. Dengan kata lain perlindungan hukum sebagai suatu gambaran dari fungsi hukum yaitu

${ }^{9}$ C.S.T Kansil, C.S.T. Kansil, Pengantar Ilmu Hukum dan Tata Hukum Indonesia, Jakarta: Balai Pustaka, 1989, hlm.38.

${ }^{10} \mathrm{Ibid}$ 
Wicaksono Putra Hariyadi, Perlindungan Hukum Hak-Hak Masyarakat Hukum Adat Terhadap Dampak Negatif Illegal Logging, Halaman 234-246

konsep dimana hukum dapat memberikan suatu keadilan, ketertiban, kepastian, kemanfaatan dan kedamaian.

Salah satu bentuk kejahatan di bidang kehutanan adalah pencurian kayu atau pembalakan kayu atau lebih dikenal dengan istilah illegal logging. Dalam Undang-Undang Nomor 41 Tahun 1999 tentang Kehutanan tidak menyebutkan secara khusus dengan istilah illegal logging sebagai suatu tindak pidana. Berdasarkan terminologi, pengertian illegal berarti tidak legal, tidak sah, tidak resmi, tidak menurut hukum, atau melanggar hukum, sedangkan logging berarti memotong atau menebang kayu. Jadi illegal logging berarti kegiatan penebangan kayu yang tidak ilegal, tidak sah, tidak resmi, tidak menurut hukum atau melanggar hukum. Definisi illegal logging menurut International Tropical Timber Organization (ITTO) adalah kegiatan logging yang tidak menerapkan asas kelestarian (unsustainable forest management). Jika dikaitkan dalam praktek, pengertian (illegal logging) terbagi 2 (dua). Yaitu pengertian secara sempit dan pengertian secara luas. Pengertian secara sempit hanya menyangkut penebangan kayu secara liar, sedangkan secara luas menyangkut setiap perbuatan atau tindakan pelanggaran dalam kegiatan kehutanan yang meliputi perizinan, persiapan operasi, kegiatan produksi, pengangkutan tata usaha kayu, pengolahan dan pemasaran. $^{11}$

Menurut Forest Watch Indonesia (FWI), illegal logging terdiri dari dua bentuk yaitu:

1. Dilakukan oleh operator sah yang melanggar ketentuan-ketentuan dalam izin yang dimiliki;

2. Melibatkan pencurian kayu, dimana pohon-pohon ditebang oleh orang yang sama sekali tidak mempunyai hak untuk menebang pohon. ${ }^{12}$

Berdasarkan penjelasan tersebut dapat dijelaskan bahwa Illegal logging merupakan suatu mata rantai yang sangat rapi dan saling terkait diantara beberapa instansi dan pelaku, yang dimulai dari sumber atau prosedur kayu illegal atau yang melakukan penebangan kayu secara illegal hingga pemasaran ke konsemen atau pengguna kayu illegal tersebut. Kayu-kayu tersebut melaui proses penebangan, pengolahan, penyaringan, pengiriman dan ekspor yang semuanya

\footnotetext{
${ }^{11}$ Abdul Hakim, Pengantar Hukum Kehutanan Indonesia, Bandung: PT. Citra Aditya Bakti, 2005, hlm. 165.

12 Suriansyah Murhaini, Hukum Kehutanan "Penegakan Hukum Terhadap Kejahatan di Bidang Kehutanan”, Yogyakarta: Laksbang Grafika, 2012, hlm. 30.
} 
Wicaksono Putra Hariyadi, Perlindungan Hukum Hak-Hak Masyarakat Hukum Adat Terhadap Dampak Negatif Illegal Logging, Halaman 234-246

dilakukan secara illegal. Bahkan kerapkali terjadi kayu-kayu yang mulanya illegal tersebut dicuci terlebih dahulu (log laundering) artinya kayu-kayu yang mulanya illegal tersebut kemudian dilegalkan oleh pihak tertentu yang bekerjasama dengan oknum aparat dan pejabat instansi kehutanan, sehingga kayu tersebut akan sulit teridentifikasi mana yang legal mana yang tidak legal. ${ }^{13}$

Sebenarnya payung hukum untuk melakukan pengawasan dan pemberantasan illegal logging dan illegal trade sudah cukup, walaupun diperlukan penyempurnaan yakni dengan menggunakan Undang-Undang Nomor 41 Tahun 1999 tentang Kehutanan, Undang-Undang Nomor 5 Tahun 1990 tentang Konservasi Sumber Daya Alam Hayati dan Ekosistemnya, Undang-Undang Nomor 23 Tahun 1997 tentang Pengelolaan Lingkungan Hidup dan Peraturan Pemerintah Nomor 45 Tahun 2004 tentang Perlindungan Hutan (sebelumnya Peraturan Pemerintah Nomor 28 Tahun 1985). Apalagi secara teknis telah diterbitkan:

1. Keputusan Bersama Menteri Perhubungan, Menteri Kehutanan dan Menteri Perindustrian dan Perdagangan Nomor KM.3 Tahun
2003, Nomor 22/Kpts-II/2003, dan Nomor 33/MPP/Kep/1/2003 tentang Pengawasan Pengangkutan Kayu melalui pelabuhan;

2. Keputusan Menteri Perindustrian dan Perdagangan Nonor 68/ MPP/Kep/2/2003 tentang Perdagangan Kayu Antarpulau. ${ }^{14}$ Yang diperlukan saat ini tinggal komitmen semua pihak, terutama aparat penegak hukum terhadap pemberantasan illegal logging dan illegal trade melalui penegakkan hukum secara konsisten dan konsekuen khususnya dalam rangka memberikan perlindungan hukum bagi hak-hak masyarakat hukum adat sebagai akibat adanya illegal logging yang membawa dampak negatif pada masyarakat adat karena hutan sebagai sumber kehidupan masyarakat adat telah ditebang tidak resmi, sehingga sumber mata air menjadi tidak layak memenuhi kesehatan akibat pencemaran lingkungan, tanah ulayat diambil secara paksa sehingga menyulut terjadinya konflik dikarenakan kurangnya pengawasan dari pemerintah terhadap illegal logging bahkan pemerintah turut serta menjadi pihak yang mensukseskan terjadinya illegal logging ini.

${ }^{14}$ Abdul Hakim, Op.Cit., hlm.170. 
Wicaksono Putra Hariyadi, Perlindungan Hukum Hak-Hak Masyarakat Hukum Adat Terhadap Dampak Negatif Illegal Logging, Halaman 234-246

Diperlukannya perlindungan hukum terhadap hak-hak masyarakat adat dikarenakan pada penerapannya banyak terjadi pelanggaran hak sehubungan adanya illegal logging ini, hal ini menunjukkan tidak efektifnya perlindungan hukum yang diberikan bagi masyarakat adat. Hal ini diperkuat dengan tidak terdapatnya rumusan secara eksplisit dan spesifik mengenai illegal logging didalam Undang-Undang Kehutanan, dan ini merupakan masalah tersendiri dalam upaya penegakkan hukum. Hanya ada beberapa pasal saja didalam Undang-Undang tersebut yang menyebutkan tindakan-tindakan apa saja yang dilarang, dapat dijadikan dasar dakwaan jika terjadi pelanggaran dibidang kehutanan sebagaimana tercantum dalam ketentuan Pasal 50 ayat 2, Pasal 50 ayat 3 huruf a,b,c,d,e,f Undang-Undang Nomor 49 Tahun 1999 tentang Kehutanan. ${ }^{15}$ Kondisi ini akan membuka celah bagi pihak-pihak yang tidak bertanggungjawab untuk melakukan perbuatan-perbuatan yang merugikan kepentingan masyarakat hukum adat sehubungan adanya illegal logging. Perlindungan hukum ini akan bertambah sulit untuk berlaku efektif dikarenakan hukum adat yang dahulunya merupakan sumber hukum nasional untuk melindungi kepentingan masyarakat hukum adat, sekarang menjadi tidak jelas letaknya sebagai sumber hukum dalam tata urutan peraturan perundang-undangan. Hukum adat hanya dapat berlaku apabila tidak bertentangan dengan ketentuan yang berlaku dalam hukum nasional. Hal ini mengakibatkan adanya ketimpangan dalam pemberian perlindungan hukum bagi masyarakat hukum adat.

Perlindungan hukum bagi masyarakat hukum adat berkaitan dengan dampak yang ditimbulkan akibat adanya illegal logging dapat ditemukan dalam konsep hukum nasional yaitu pada ketentuan Pasal 67 Undang-Undang Nomor 41 Tahun 1999 menjelaskan bahwa masyarakat hukum adat diakui keberadaannya, jika menurut kenyataannya memenuhi unsur antara lain:

1. Masyarakatnya masih dalam bentuk paguyuban (rechtsgemeenshap);

2. Ada kelembagaan dalam bentuk perangkat penguasa adatnya;

3. Ada wilayah hukum adat yang jelas;

4. Ada pranata dan perangkat hukum, khususnya peradilan adat yang masih ditaati;dan 
Wicaksono Putra Hariyadi, Perlindungan Hukum Hak-Hak Masyarakat Hukum Adat Terhadap Dampak Negatif Illegal Logging, Halaman 234-246

5. Masih mengadakan pemungutan hasil hutan di wilayah hutan sekitarnya untuk pemenuhan kebutuhan hidup sehari-hari. ${ }^{16}$

Penjelasan Pasal 67 ayat (2) menyatakan bahwa Peratuuran Daerah disusun dengan mempertimbangkan hasil penelitian para pakar hukum adat, aspirasi masyarakat hukum setempat dan tokoh masyarakat adat yang ada di daerah yang bersangkutan, serta instansi pihak lain yang terkait, selanjutnya penjelasan Pasal 67 ayat 3 menyatakakan bahwa Peraturan Pemerintah memuat antara lain:

1. Tata cara penelitian;

2. Pihak-pihak yang diikutsertakan;

3. Materi penelitian;

4. Kriteria penilaian berdasarkan keberadaan masyarakat hukum adat.

Perlindungan hukum yang diberikan bagi masyarakat hukum adat sehubungan dampak yang ditimbulkan akibat adanya illegal logging berkaitan pula dengan konsep teori keadilan dan teori perlindungan hukum. Dalam bukunya "Rhetorica" Aristoteles mencetuskan teorinya bahwa tujuan hukum menghendaki keadilan semata-mata dan isi dari pada hukum ditentukan oleh kesadaran etis mengenai apa yang

${ }^{16}$ Ibid, hlm. 245 . dikatakan adil dan tidak adil. Menurut teori ini hukum mempunyai tugas suci dan luhur, ialah keadilan dengan memberikan kepada tiap-tiap orang apa yang berhak ia terima yang memerlukan peraturan tersendiri bagi tiap-tiap kasus. Oleh karenanya hukum harus membuat apa yang dinamakan "Algemeene regels" (peraturan atau ketentuan umum). Peraturan ini diperlukan oleh masyarakat teratur demi kepentingan kepastian hukum, meskipun suatu waktu dapat menimbulkan ketidakadilan. 17 Aristoteles dalam tulisannya Rhetorica, membedakan dua macam keadilan yaitu keadilan komutatif dan keadilan distributif. Perlindungan hukum bagi masyarakat hukum adat mempergunakan konsep keadilan distributif yang merupakan keadilan yang memberikan pembagian pada setiap orang berdasarkan haknya masing-masing. ${ }^{18}$

Teori perlindungan hukum juga dipergunakan sehubungan dengan pemberian perlindungan hukum bagi masyarakat hukum adat. Fitzgerald menjelaskan hukum melindungi kepentingan seseorang dengan cara

${ }^{17}$ R. Soeroso, Pengantar Ilmu Hukum, Jakarta: Sinar Grafika, 2007, hlm.58.

18 C.S.T. Kansil, Pengantar Ilmu Hukum dan Tata Hukum Indonesia, Jakarta: Balai Pustaka, 1989, hlm .42-43. 
Wicaksono Putra Hariyadi, Perlindungan Hukum Hak-Hak Masyarakat Hukum Adat Terhadap Dampak Negatif Illegal Logging, Halaman 234-246

mengalokasikan kekuasaan kepadanya secara terukur untuk bertindak dalam rangka kepentingannya yang disebut dengan hak. Keperluan hukum adalah mengurusi hak dan kepentingan manusia, sehingga hukum memiliki otoritas tertinggi untuk menentukan kepentingan manusia yang perlu dilindungi dan diatur yang tertuang dalam bentuk peraturan. ${ }^{19}$

Menurut Satjipto Raharjo, perlindungan hukum adalah memberikan pengayoman terhadap hak asasi manusia yang dirugikan orang lain dan perlindungan itu diberikan kepada masyarakat agar dapat menikmati semua hak-hak yang diberikan oleh hukum. ${ }^{20}$ Menurut Lili Rasyidi dan I.B Wysa Putra berpendapat bahwa hukum dapat difungsikan untuk mewujudkan perlindungan yang sifatnya tidak sekedar adaptif dan fleksibel, melainkan juga prediktif dan antisipatif. ${ }^{21}$

Berdasarkan uraian diatas, menunjukkan bahwa perlindungan hukum bagi masyarakat hukum adat terhadap dampak negatif illegal logging berdasarkan konsep hukum nasional dan

${ }^{19}$ J.HAL. Fitzgerald, dalam Satjipto Rahardjo, Ilmu Hukum, Bandung: PT. Citra Aditya Bakti, 2000, hlm. 69.

${ }^{20}$ Satjipto Rahardjo, Ilmu Hukum, Bandung: PT. Citra Aditya Bakti, 2000, hlm. 53.

${ }^{21}$ Lili Rajidi dan I.B Wysa Putra, Hukum Sebagai Suatu Sistem, Bandung: Remaja Rusdakarya, 1993, hlm.118 hukum adat masing-masing mempunyai konsep tersendiri. Berdasarkan konsep hukum nasional dapat ditemukan peraturan perundang-undangan yang memberikan perlindungan hukum pada masyarakat adat sehubungan adanya dampak negatif dari illegal logging yaitu Pasal 67 ayat (1) (2) dan (3) Undang-Undang Nomor 41 Tahun 1999 tentang Pokok-Pokok Kehutanan. Peranan pemerintah dalam melindungi hak-hak masyarakat hukum adat dapat ditemukan dalam berbagai ketentuan peraturan perundang-undangan antara lain UUD 1945, Pasal 7 dan 11 Undang-Undang Nomor 32 Tahun 2004 tentang Pemerintahan Daerah, Undang-Undang Nomor 5 Tahun 1960 tentang Undang-Undang Pokok Agraria, Undang-Undang Nomor 11 Tahun 1967 tentang Pertambangan. Sedangkan perlindungan hukum bagi masyarakat hukum adat dengan mempergunakan konsep hukum adat berisikan aturan-aturan hukum yang berurat akar kepada kebudayaan tradisional, sehingga menjelmakan perasaan hukum rakyat yang nyata.

\section{PENUTUP}

Bentuk dan mekanisme perlindungan hukum hak-hak masyarakat hukum adat 
Wicaksono Putra Hariyadi, Perlindungan Hukum Hak-Hak Masyarakat Hukum Adat Terhadap Dampak Negatif Illegal Logging, Halaman 234-246

terhadap dampak negatif illegal logging berdasarkan konsep hukum nasional dan hukum adat dapat dilakukan dengan melindungi kepentingan masyarakat adat khususnya melalui peraturan perundang-undangan yaitu dalam Pasal 67 Pasal (1) (2) dan (3) Undang-Undang Nomor 41 Tahun 1999 tentang Kehutanan. Perlunya perlindungan hukum ini dikarenakan masyarakat adat rentan terhadap pelanggaran atau pengabaian hak asasinya. Negara mempunyai tanggung jawab untuk memajukan, melindungi serta menegakkan hak asasi manusia terhadap warganya. Sedangkan melalui konsep hukum adat dilakukan dengan mempergunakan aturan hukum adat yang berisikan aturan-aturan hukum yang berurat akar kepada kebudayaan tradisional, sehingga menjelmakan perasaan hukum rakyat yang nyata.

Masyarakat hukum adat hendaknya mendapatkan perlindungan hukum yang maksimal dalam mendapatkan haknya untuk dapat memanfaatkan dan mengelola sumber daya hutan dapat berjalan sesuai fungsinya berdasarkan atas konsep hukum nasional dan hukum adat,sehingga tetap dapat dimanfaatkan bagi kebutuhan generasi berikutnya.

\section{DAFTAR PUSTAKA}

Abdul Muis Yusuf dan Mohammad Taufik Makarao, Hukum Kehutanan di Indonesia, Jakarta: Rineka Cipta, 2011.

Abdul Hakim, Pengantar Hukum Kehutanan Indonesia, Bandung: PT. Citra Aditya Bakti, 2005.

C.S.T. Kansil, Pengantar Ilmu Hukum dan Tata Hukum Indonesia, Jakarta: Balai Pustaka, 1989.

Chairul Anwar, Hukum Adat Indonesia "Meninjau Hukum Adat Minangkabau”, Jakarta: Rineka Cipta, 1997.

E.Utrecht dan Moh. Saleh Djindang, Pengantar dalam Hukum Indonesia, Jakarta: PT Ichtiar Baru, Anggota IKAPI dan Penerbit Sinar Harapan, 1989.

Lili Rajidi dan I.B Wysa Putra, Hukum Sebagai Suatu Sistem, Bandung: Remaja Rusdakarya, 1993.

Moh. Koesnoe, Hukum Adat Sebagi Suatu Model Hukum, Bandung: CV. Mandar Maju, 1992.

R. Soeroso, Pengantar Ilmu Hukum, Jakarta: Sinar Grafika, 2007.

Satjipto Rahardjo, Ilmu Hukum, Bandung: PT. Citra Aditya Bakti, 2000. 
Wicaksono Putra Hariyadi, Perlindungan Hukum Hak-Hak Masyarakat Hukum Adat Terhadap Dampak Negatif Illegal Logging, Halaman 234-246

Salim HS, Dasar-Dasar Hukum Soerjono Soekanto, Hukum Adat Kehutanan, Jakarta: Sinar Grafika, Indonesia, Jakarta: PT. 2008.

RajaGrafindo Persada, Jakarta,

Salim HS, Perkembangan Teori dalam 2007.

Ilmu Hukum, Jakarta: Rajawali Pers, 2010.

Suriansyah Murhaini, Hukum Kehutanan "Penegakan Hukum Terhadap

Supriadi, Hukum Kehutanan dan Hukum Kejahatan di Bidang Kehutanan”, Perkebunan di Indonesia, Jakarta: Yogyakarta: Laksbang Grafika, Sinar Grafika, 2010. 2012. 